\title{
Fire Effects on the Biological and Geological Characteristics of Sediments in Yellowstone LAKE: A BaSIS FOR IMPROVED Fire Management Policy
}

\author{
BRIAN R. SHERo \\ Medaille College \\ BuFfaLo, New York
}

\author{
JILL K. SiNGER \\ State UNIVERsity College \\ Buffalo, NEW YoRK
}

\section{$\downarrow$ OвJECTIVES}

A number of studies have examined the effect of forest fires on the nutrient and productivity levels of lakes and streams, but no consistent pattern has been identified. In the specific case of Yellowstone Lake, Romme and Knight (1982) and Albin (1979) suggested that cyclic fires in the Yellowstone Lake drainage basin could potentially increase nutrient loading of the lake and thereby increase its productivity.

This study proposes to measure the effects of the 1988 fires on Yellowstone Lake by examining sediments currently being deposited in the Lake (experimental) and comparing these sediments with older sediments collected from the Lake bottom (control or background). Four sediment traps collected sediments at two sites near the Pelican Creek inlet between March and November 1989. Differences between the sediment trap samples (experimental) and the uppermost lake sediments (control) will be the basis for evaluating the effect of the fires on lake ecology with a particular emphasis on diatoms, the major primary producers in the lake. Differences in sedimentation processes will also be evaluated based on the physical and chemical analysis of the experimental and control samples.

The second question which we are examining in our research is the long-term fire history in Yellowstone National Park. If fires of the magnitude of 1988 alter the characteristics of sediments being deposited in Yellowstone Lake, then the lake sediments should contain "signals" of previous large fires in the form of altered sediment composition (particle size, charcoal, diatom assemblages). We collected a series of gravity cores (large and small diameter) near the sediment trap sites to look for potential fire "signals".

\section{$\downarrow$ Significance}

We will be able to determine the magnitude and rate of changes in the biological and geological characteristics of sediments being deposited in Yellowstone Lake following a large fire. Our sediment traps were the only sampling equipment in place to collect sediments from the spring 1989 snowmelt runoff, which we expect to best reflect fire effects. 
The biological and geological characteristics which we measure in the 1989 and 1990 sediments will be used as a calibration index to evaluate the record of previous fires preserved in older lake sediments. These older lake sediments potentially contain a record of fires extending back to the immediate post-glacial period. This calibration plan is unique and will provide a needed validation for many previous paleolimnological studies. Only by examining the direct effect of fire on sediments currently being deposited can we accurately interpret older sediments and reconstruct a fire history.

\section{$\downarrow$ Methods}

Four sediment traps were deployed in Yellowstone Lake from March - November 1989. A pair of traps, one approximately $2 \mathrm{~m}$ below the water surface and the other approximately $2 \mathrm{~m}$ above the bottom, were anchored at two locations ( $16 \mathrm{~m}$ and $20 \mathrm{~m}$ depths) at the Pelican Creek inlet on the north side of Yellowstone Lake. Sediments collected in these traps were removed approximately every 2-3 weeks during the 1989 period. Our 1990 sediment trap samples were too irregular in timing and location to be used in this study. Between November 1989 and summer of 1990, three traps were lost and the fourth was washed on to shore.

During the week of August 5, 1990, lake bottom sediments were sampled near the trap sites. Undisturbed upper sediment samples from the lake bottom were collected using a Hongve corer. Four cores were obtained and sectioned at approximately 1 $\mathrm{cm}$ intervals, resulting in approximately 60 samples for analysis. four larger diameter $(3 "$ or $7.6 \mathrm{~cm})$ and longer length (1-2 $\mathrm{m})$ cores were also collected near the sediment trap sites. These longer sediment sequences will be $\mathrm{X}$-rayed prior to sampling. $\mathrm{X}$ radiographs of cores will augment the visual description of the sediment sequences and permit identification of subtle or fine-scale sedimentary structures, such as laminations.

Sediment samples collected through coring and in the sediment traps will be analyzed to determine the relative contributions of biogenic and terrigenous material. Because the biogenic component is dominated by diatoms, determination of biogenic silica content allows the biogenic to non-biogenic (i.e. terrigenous) contribution to be evaluated. Downcore biogenic silica determinations will be made at $2 \mathrm{~cm}$ (approximately $20 \mathrm{yr}$.) intervals. This should permit short-term fluctuations in biogenic silica content (diatoms) to be identified.

The weight percent of biogenic silica can be determined using a colormetric technique outlined by DeMaster (1979). Approximately 10 to $20 \mathrm{mg}$ of sediment is leached at $85^{\circ} \mathrm{C}$ for 5 hours in a $.1 \mathrm{M}$ $\mathrm{NaOH}$. The amount of silica extracted hourly is measured using the molybdate-blue spectrophotometric method of Strictland and Parsons (1968). The intensity of the blue color is measured on a spectrophotometer and is compared to a set of standards of known concentration. This method will be modified (Dunbar, personal communication) to take into account the presence of volcanic glass shards.

The size distribution of particles in the water column and lake bottom sediments also will be determined. Samples will be analyzed using a SediGraph, an instrument which measures particle size as a function of settling rate and particle density. Downcore textural (size) variability, coupled with the compositional data, will provide a means to evaluate sediment sources and transport paths.

We will also construct $\mathrm{Pb}-210$ profiles for one or more of the cores we collect. These analyses will be conducted at the Nuclear Facility at Chalk river, Ontario on a contract basis. The $\mathrm{Pb}-210$ profiles will enable us to determine sediment accumulation rates. When coupled with the biogenic silica determinations, the sediment accumulation rates will reflect the productivity of diatoms in Yellowstone Lake.

In addition, by determining sedimentation rates for our cored sequences, the charcoal accumulation rate can be calculated using the method outlined by Winkler (1985). This procedure involves the nitric acid digestion of sediment samples to remove all organic material, carbonates, and pyrite; charcoal carbon and inorganic material remain. The sample is ignited $\left(450-500^{\circ} \mathrm{C}\right.$ for $\left.3 \mathrm{hrs}\right)$ to remove charcoal carbon. Winkler's method permits calculating charcoal as a percentage of the dry weight of the sample, and has been shown to give results comparable to counting of microscopic charcoal (Winkler 1985).

Diatom assemblages will be examined using standard techniques as described by Patrick and Reimer (1966). The technique involves digesting the 
sample in nitric acid to solubilize the organic component. The digested samples are repeatedly washed until only the silica minerals and diatoms remain. These remaining materials are then placed in special evaporating trays (Battarbee trays). The water is allowed to evaporate and the diatoms are deposited on coverslips. Hyrax mounting medium is used to attach these coverslips to microscope slides.

The prepared slides will be used to determine taxonomy of the species at $1000 x$. Black and white photographs will be used to document these identifications. Transect counts will then be made on each sample until a total of at least 500 frustules have been counted. Percent abundance and biovolume comparisons will then be calculated and graphed for all samples.

\section{$\downarrow \quad$ Preliminary Results}

Field work was completed and resulted in four large diameter and four small diameter sediment cores for analyses. Sediment trap samples from May November 1989 will be analyzed as described above. Sediment trap samples from 1990 are either absent or unreliable.

\section{$\downarrow$ Continuing Research}

Laboratory analyses are currently in progress. A plan is being developed to continue collecting sediment trap samples during 1991, regardless of continued funding.

\section{$\downarrow \quad$ Literature Cited}

Albin, D. P. 1979. Fire and stream ecology in some Yellowstone Lake tributaries. Calif. Fish and Game 65:216-238.

De Master, D. D. 1979. The marine budgets of silica and Si. Unpublished Ph.D. Thesis, Yale University, New Haven, Conn.

Patrick,, R., and C. W. Reimer. 1966. The diatoms of the United States. Acad. Nat. Sci. Phila. No. 13, Vol. 1.

Romme, W. H., and D. H. Knight. 1982. Landscape diversity: The concept applied to Yellowstone Park, Bioscience 32:664-670.

Winkler, M. G. 1985. Charcoal analysis for paleoenvironmental interpretation: A chemical assay. Quat. Res. 23:313-326. 